ARTICLE HISTORY: Received: August: 6, 2021 Accepted: September 27, 2021 Published: October 4, 2021

\title{
PUBLIC CONTROL AND NATURAL RESOURCE CADASTRAL ACTIVITY
}

\author{
RobiyaToshboyeva \\ Tashkent State Law University, \\ Acting Associate Professor of Bisness Law, \\ Candidate of Legal Sciences
}

\begin{abstract}
The article reveals the importance of public environmental control in the implementation of natural resource cadastral activities for the collection, processing, storage and provision of information on the qualitative and quantitative state of natural resources from the perspective of the public's impact on solving environmental problems in general. The author analyzes some issues of further improvement of public environmental control in natural resource cadastral activities and puts forward proposals for further improvement of cadastral legislation.

Keywords: public environmental control, natural resource cadastral activity, public environmental inspector, information and communication technologies, land plot monitoring, public environmental control inspector
\end{abstract}

Strengthening the role of civil society in solving problems in the field of environmental protection is one of the main tasks of the Concept of Environmental Protection of the Republic of Uzbekistan until 2030 [1] and is expressed, in particular, in the form of public environmental control.

Public environmental control in the context of climate change is the starting point in solving urgent environmental problems. The dominant element in this case is the functioning of an information system on the state of the environment, an integral part of which is natural resource cadastral information.[2]The purpose of this information system is to ensure the realization of everyone's right to a favorable environment, to establish mechanisms for consideration by authorized executive authorities of the results of public control in the field of environmental protection (public environmental control), to improve the efficiency of public administration in the field of environmental protection.

The natural resource cadastral system of Uzbekistan, in which natural resource cadastral information is formed, has undergone fundamental changes over the past five years, aimed at achieving transparency of the system of formation and provision of cadastral information [3].

Natural resource cadastral activity as one of the elements of state management in the field of environmental protection should be the object of public environmental control, that is, a system of public measures aimed at preventing, detecting and crossing violations of the requirements of legislation in the field of environmental protection and rational use of natural resources, improving the efficiency of environmental protection activities

Public environmental control in Uzbekistan is carried out in accordance with the laws of the Republic of Uzbekistan "On nature protection", "On environmental control", "On public control", "On public health protection", Resolution of the Cabinet of Ministers of the Republic of Uzbekistan "On approval of standard provisions for the implementation of public environmental control" dated October 8, 2015 No. 287 and other regulatory legal acts.

In accordance with the above-mentioned acts, public environmental control in the field of cadastral activity is carried out by citizens ' self-government bodies, non-governmental non-profit organizations, citizens by analyzing and evaluating the state of the environment and the rational use of natural resources, as well as studying public opinion.

The importance of public environmental control is indicated by the fact that it is directly fixed in the relevant regulatory legal acts related to the rational use of natural resources. [4]

The procedure for implementing public environmental control is regulated by the Model Regulation on the Procedure for Implementing Public Environmental Control, according to which the above-mentioned entities in the field of natural resource cadastral activities have the right to participate in informing state and other organizations and citizens about changes in the environment, the use of natural resources and the appropriate measures taken.

In order to exercise this right, they are, in particular, entitled to apply to the relevant State bodies and receive information about the state of the environment, the rational use of natural resources, measures taken to eliminate the revealed fact of violation of legislation in this area.

The results of public environmental control in the field of cadastral activities can be expressed in the form of informing specially authorized state bodies, local public authorities and citizens about the results of public environmental control, as well as making proposals to the relevant state bodies to take measures on the identified violation of the requirements of legislation in the field of environmental protection and rational use of natural resources.

In the legal literature, there is a different approach to determining the legal status of subjects of public environmental control.

Thus, according to Utegenov O. D., citizens, self-government bodies and non-governmental non-profit organizations are the main subjects of public environmental control over the implementation of legislation on the protection and use of the animal and plant world [5]. 
At the same time, according to Ivleva A. F., the exclusion from the control of compliance with the requirements of the legislation on land from the sphere of public land control is justified.[6] Vinokurov A. Yu. considers it necessary to legislatively specify the functions of verification public control in order to avoid the possibility of qualifying the actions of public controllers as arbitrariness [7].

A separate subject of public environmental control is a public inspector of environmental control, whose legal status is defined in the Standard Provision "On public inspector of environmental control".

Any citizen of the Republic of Uzbekistan who has expressed his will to become a public inspector of environmental control can become a public inspector. To do this, you must apply at your place of residence to the Citizens ' Assembly Commission for Ecology and Environmental Protection, Landscaping and Landscaping, or to a nongovernmental non-profit organization that carries out its activities in the field of environmental protection.

In our opinion, it is public environmental control inspectors who should become the key subjects of public control in the implementation of public environmental control in the natural resource cadastral sphere, with their close interaction with other civil society institutions with the extensive use of information and communication technologies.

The current legislation establishes the general tasks of the public inspector of environmental control, which include: prevention, detection and suppression of violations of the requirements of legislation in the field of environmental protection and rational use of natural resources;

monitoring the state of the environment, irrational use of natural resources, pose a threat to the life and health of citizens;

determination of compliance with the environmental requirements of the planned or ongoing economic and other activities;

participation in ensuring compliance with the rights and legitimate interests of legal entities and individuals, their performance of duties in the field of environmental protection and national use of natural resources;

participation in informing state and other organizations and citizens about changes in the environment, forecasts of its state, the use of natural resources and the appropriate measures taken;

improving the effectiveness of environmental protection activities and ensuring the participation of citizens ' selfgovernment bodies, non-governmental non-profit organizations and citizens in the implementation of state and other environmental programs

carrying out work on educating citizens to respect the surrounding natural environment, promoting and spreading knowledge about nature, participating in the organization and holding of competitions, exhibitions and other mass events on environmental topics.

When implementing public environmental control, we propose to expand the rights of a public inspector directly in natural resource cadastral activities by:

1 providing an opportunity to initiate the introduction of information about protected areas of local significance in the state cadastre of protected natural territories;

2 securing the authority to regularly study the results of the treatment of individuals and legal entities to provide information on the state of natural resources;

3 creating conditions for studying the state of use of cadastral information on natural resources by local state authorities when solving issues of local significance.

Speaking about public environmental control in the natural resource cadastral sphere, we cannot but dwell on the activities of such a large non-governmental non-profit organization as the Council of Farmers, Dehkan Farms and Owners of Household Lands of Uzbekistan.

Decree of the President of the Republic of Uzbekistan No. UP-5199 dated October 9, 2017 "On measures to radically improve the system of protecting the rights and legitimate interests of farmers, Dehkan farms and the owner of household lands, effective use of agricultural acreage" defined the main tasks and activities of the Council of Farmers, Dehkan farms and owners of household lands of Uzbekistan. These include, in particular,:

protection of the rights and legitimate interests of farmers, dehkan farms and owners of household lands, including in relations with state and economic management bodies, local state authorities, organizations for procurement, supply and provision of services, in the process of inspections by regulatory authorities, as well as when considering cases in courts;

comprehensive support of dehkan farms and owners of household lands in the production, processing, storage and sale of agricultural products, including in the implementation of agrotechnical measures, as well as the drafting of contracts, the export of products to foreign markets;

strengthening of contractual discipline in agriculture, implementation of comprehensive measures to improve the legal literacy and culture of managers of farms, dehkan farms and owners of household lands, improvement of labor relations in the agricultural sector;

stimulating joint cooperation with the self-government bodies of citizens of farmers, dehkan farms and owners of household lands who effectively carry out their activities, taking measures of influence through public influence in relation to landowners who admit shortcomings in their activities; 
assistance in the development and comprehensive support of multidisciplinary farms, direct participation in the formation of a favorable business environment for them;

adoption of practical measures for the development of farms specialized in animal husbandry, poultry farming, fish farming, beekeeping and other areas, wide popularization of the experience of model farms operating in these areas, etc.

At the same time, by the Decree of the President of the Republic of Uzbekistan No. PP-3680 of April 26, 2018, the powers of the Council of Farmers, Dehkan farms and owners of household lands of Uzbekistan were expanded by monitoring and public control over the fulfillment of contractual obligations in agriculture with the participation of farmers, dehkan farms and owners of household lands.

In addition, monitoring the condition of the land plot of the owners of household plots is one of the main functions of public control in the conduct of cadastral activities.

The same normative legal act in the field of public control over cadastral activities expanded the powers of selfgovernment bodies, in particular, every year until February 1, the chairmen of the self-government bodies of citizens, together with the inspectors for the prevention of internal affairs bodies, by going around the houses, should conduct an inventory of the acreage of dehkan farms and owners of household lands on the territory, determine, in the context of parts for the needs of the family and intended for sale, the types of crops and the volume of products produced during the year, organize public control over the conclusion of contracts for the production of products, complete and highquality sowing of crops, timely implementation of agrotechnical measures.

As can be seen from the above analysis of the legislation, the Republic of Uzbekistan has formed a regulatory and legal framework for the implementation of public control in the field of natural resource cadastral activities, especially by public organizations endowed with certain powers in the field of ensuring environmental safety in general.

Today, the main task of public control in the natural resource cadastral system is to further improve the information system of public control, aimed at collecting and processing appeals from citizens, public associations and other nonprofit organizations containing information indicating the presence of violations of natural resource cadastral legislation through the use of information and telecommunications technologies, provision by the competent authorities of electronic messages to nature users on the results of consideration of information appeals regarding violations of the procedure for forming, processing and providing information about natural resources to interested persons.

Practical measures are already being taken in Uzbekistan in this regard. In particular, the Prosecutor General's Office of the Republic of Uzbekistan has developed a special telegram bot program "YER NAZORAT" for the implementation of public environmental control in the field of land use, which allows collecting operational information about offenses related to the use of land and other factors that negatively affect the quantitative and qualitative state of land resources. But these measures alone are not enough for the full-scale implementation of public environmental control.

It would be advisable to make greater use of the possibilities of information and communication technologies in this area, in particular, to develop mobile applications for the organization of public environmental control in the natural resource cadastral system, the operator and state customer of which should be the State Committee for Ecology and Environmental Protection of the Republic of Uzbekistan. Thanks to these technologies, subjects of public environmental control in the field of natural resource cadastral activity can inform the competent environmental control authorities about the facts of pollution of water bodies, illegal deforestation, violation of boundary signs and other offenses in the natural resource cadastral system, while the facts of offenses can be confirmed by photo and video materials indicating the exact location of violations or their coordinates.

\section{References.}

1. Decree of the President of the Republic of Uzbekistan "On approval of the concept of environmental protection of the Republic of Uzbekistan until 2030" https://lex.uz/docs/4574010

2. Тошбоева Р. ПРАВОВЫЕ ВОПРОСЫ ВЫДЕЛЕНИЯ ЗЕМЕЛЬНЫХ УЧАСТКОВ ДЛЯ ОСУЩЕСТВЛЕНИЯ ПРЕДПРИНИМАТЕЛЬСКОЙ ДЕЯТЕЛЬНОСТИ //Review of law sciences. - 2018. - №. 4.

3. ТОШБОЕВА, Р. (2021). РЕФОРМИРОВАНИЕ ПРИРОДНОРЕСУРСОВОЙ КАДАСТРОВОЙ СИСТЕМЫ УЗБЕКИСТАНА: СОВРЕМЕННЫЕ ТЕНДЕНЦИИ И ПУТИ ИХ ПРАВОВОЙ РЕГЛАМЕНТАЦИИ. ЮРИСТ АХБОРОТНОМАСИ , 2 (1), 74-85.

4. Decree of the President of the Republic of Uzbekistan" On approval of the Concept of water management development of the Republic of Uzbekistan for 2020 - 2030 " dated July 10, 2020, No. UP-6024 https://lex.uz/docs/4892946

5. Utegenov O. D. Ecology of the soacuasida zhamoatchilik nazoratini xukukiy ta'minlashni takomillashtirish. Jurist fanlari doktori (Ds) dissertationsi autoreferati.T., 2020, TDUU, 46 b.

6. Ivleva A. F. Legal bases of public control in the field of nature management and environmental protection in Russia https://cyberleninka.ru/article/n/pravovye-osnovy-obschestvennogo-kontrolya-v-oblasti-prirodopolzovaniya-iohrany-okruzhayuschey-sredy-v-rossii/viewer (accessed 30.06.2021)

7. Vinokurov A. Yu. Public environmental control: current state and prospects $\backslash \backslash$ Environmental Law, 2014, No. 3, p. 17 
8. Тошбоева, Р. С. (2020). ЭКОЛОГИЗАЦИЯ ЭКОНОМИКИ УЗБЕКИСТАНА: ПРАВОВОЙ АСПЕКТ СОВЕРШЕНСТВОВАНИЯ ИНВЕСТИРОВАНИЯ. ЖУРНАЛ ПРАВОВЫХ ИССЛЕДОВАНИЙ, (SPECIAL 5). 